\title{
Resveratrol analogue $(E)-8$-acetoxy-2-[2-(3,4-diacetoxyphenyl) ethenyl]-quinazoline induces apoptosis via Fas-mediated pathway in HL-60 human leukemia cells
}

\author{
EUN YOUNG PARK ${ }^{1 *}$, JOO-IL KIM $^{1 *}$, DONG-GYU LEEM ${ }^{1,4}$, JI-SUN SHIN $^{1}$, KYUNG-TACK KIM ${ }^{4}$, \\ SANG YOON $\mathrm{CHOI}^{4}, \mathrm{MYUNG} \mathrm{HEE} \mathrm{LEE}^{4}$, JUNG-HYE CHOI ${ }^{2,3}$, YONG SUP LEE $^{2}$ and KYUNG-TAE LEE ${ }^{1,2}$ \\ Departments of ${ }^{1}$ Pharmaceutical Biochemistry, ${ }^{2}$ Life and Nanopharmaceutical Science and \\ ${ }^{3}$ Oriental Pharmaceutical Science, College of Pharmacy, Kyung Hee University, Seoul 130-701; \\ ${ }^{4}$ Traditional Food Research Center, Korea Food Research Institute, Seongnam 13539, Republic of Korea
}

Received May 18, 2016; Accepted October 3, 2016

DOI: $10.3892 /$ or.2016.5168

\begin{abstract}
Previously, we reported that (E)-8-acetoxy-2-[2(3,4-diacetoxyphenyl)ethenyl]-quinazoline (8-ADEQ), a synthetic analogue of resveratrol had anti-inflammatory and $\mathrm{G}_{2} / \mathrm{M}$ cell cycle arrest activities, but the underlying molecular mechanism of cytotoxic effects of this compound was not determined. In this study, 8-ADEQ displayed potent cytotoxicity and triggered apoptosis in HL-60 cells as evidenced by DNA fragmentation, DNA ladder formation, and the externalization of Annexin V-targeted phosphatidylserine residues in HL-60 cells. In addition, 8-ADEQ triggered activation of caspases- $8,-9,-6$ and -3 and cleavage of their substrates such as poly(ADP-ribose) polymerase (PARP). Moreover, 8-ADEQ induced loss of mitochondrial membrane potential (MMP) and release of cytochrome $c$ to the cytosol. Caspase-3 inhibitor (z-DEVD-fmk), caspase-8 inhibitor (z-IETD-fmk), caspase-9 inhibitor (z-LEHD), and broad caspase inhibitor (z-VAD-fmk) significantly suppressed the 8-ADEQ-induced DNA fragmentation. Interestingly, pretreatment with z-IETD-fmk, a caspase-8 inhibitor, completely abolished 8-ADEQ-induced caspase-3 and -9 activation, and subsequent DNA fragmentation. 8-ADEQ also increased the expression of Fas, Fas-associated death domain (FADD) and FasL, and formation of death-inducing signaling complex (DISC). Further analysis revealed that 8-ADEQ-induced apoptosis was mediated by upregulation of reactive oxidative species (ROS) generation. Taken together, our data indicated that 8-ADEQ-stimulated apoptosis in HL-60 leukemia cells is due to a Fas-mediated
\end{abstract}

Correspondence to: Dr Kyung-Tae Lee, Department of Pharmaceutical Biochemistry, College of Pharmacy, Kyung Hee University, Dongdaemun-Ku, Hoegi-Dong, Seoul 130-701, Republic of Korea E-mail:ktlee@khu.ac.kr

*Contributed equally

Key words: styrylquinazoline analogues, apoptosis, leukemia cells, caspase-8, Fas caspase-8-dependent pathway via ROS generation, but also, to a lesser extent cytochrome $c$ release and caspase- 9 activation.

\section{Introduction}

It is known that many anticancer drugs directly induce cancer cell death through apoptosis or necrosis, and it is now increasingly accepted that activating apoptosis is a major part of the efficacy of some of the most effective anticancer drugs (1). Anticancer drugs have been reported to induce apoptosis in various cancers; these include various chemotherapeutics such as cisplatin (2), doxorubicin (3), paclitaxel (4), and etoposide (5). Besides chemotherapies, various therapeutics whether they are immunotherapy, radiation therapy or gene therapy, also trigger apoptosis or programmed cell death in their target cancer cells.

Apoptosis is characterized by condensation and fragmentation of nuclear chromatin, compaction of cytoplasmic organelles, dilatation of the endoplasmic reticulum, a decrease in cell volume and alterations to the plasma membrane (6). The remaining cell components are then engulfed by neighboring cells or macrophages. In normal cell biology, apoptosis also provides a means of purging unwanted cells and that may include defective cells. Apoptotic signaling can proceed in two pathways: originating the extrinsic death pathway, via death receptors expressed on the plasma membranes of cells or initiated intrinsic mitochondria-mediated pathway, which contain several proteins that regulate apoptosis. Among the six different death receptors, Fas (CD95), tumor necrosis factor receptor 1 (TNFR1), death receptor (DR)3, DR4, DR5, and DR6, the Fas system is a major signaling pathway involved in regulation of apoptosis according to several studies (7). The interaction of Fas with FasL induces apoptotic cell death and altered expression of Fas/FasL has also been implicated in pathogenesis of diseases associated with immune regulation (8). Ligation of the Fas receptor on the cell surface results in its trimerization and recruitment of the adaptor molecule FADD and procaspase- 8 and form the death-inducing signaling complex (DISC). Procaspase- 8 is activated at the DISC by an autocatalytic cleavage. Cells expressing and recruiting sufficient amounts 
of procaspase- 8 at the DISC undergo apoptosis through direct activation of caspase- 3 by active caspase- 8 . In contrast, cells with limited amounts of active caspase- 8 at the DISC cannot proceed through this direct pathway and depend on the release of cytochrome $c$, which leads to caspase- 9 activation and initiation of a proteolytic caspase cascade (9).

Reactive oxidative species (ROS) have been implicated in the induction or enhancement of apoptosis (10) through stress stimuli such as exposure to UV, other forms of irradiation, or cytotoxic drugs (11). However, the role of ROS in Fas-induced cell death remains uncertain (12). UV, cycloheximide, c-Jun $\mathrm{N}$-terminal kinase (JNK), and cytotoxic drugs are also reported to trigger FADD-dependent apoptosis in cancer cells (12-14). The mechanism of how FADD-caspase- 8 cascade is activated under these stress stimuli is not completely understood. An interesting possibility is that there is clustering and thus activation of Fas receptor and its interaction with FADD induced by the stress stimuli, as suggested by several studies (12-14).

It has been reported that the activation of the Fas receptor, which belongs to the TNF receptor family, results in a signal transduction pathway that most likely uses the production of ROS (15). As for the intracellular source of ROS generated with Fas-mediated signaling, both NADPH oxidase (16) and the mitochondrial electron transport chain have been implicated in different cell types (17). Counteracting the generated ROS, various antioxidants, such as $N$-acetyl-cysteine (NAC), superoxide dismutase (SOD) overexpression or catalase, block Fas-induced apoptosis (12).

Resveratrol, trans-3,5,4'-trihydroxystilbene, has demonstrated various potential activities including anticancer effects, anti-oxidant effects, and cardioprotective effects (18-20). Resveratrol is found in grapes, berries and peanuts (21), and many resveratrol derivatives have been reported to possess diverse biological effects, including anti-inflammatory (22), antitumor (23) and antiarrhythmic effects (24). In particular, the various analogues of resveratrol include: a novel resveratrol-salicylate hybrid analog with anti-inflammatory and antioxidant properties (25); astringinin, displaying a potent anti-melanoma effect (26); 3,4,5-trihydroxy-trans-stilbene, with an apoptotic activity (27); the synthetic triacetoxystilbene (TAS), with anti-inflammatory activity (28); HS-1793, a synthetic resveratrol analogue, with a modulatory effect on tumor-derived T cells (29); and 8-ADEQ, also a synthetic resveratrol analogue that displays cell cycle arrest activity (23).

Isoquinolines, in particular, have attracted research interest as potential anticancer agents as they can interfere with cellular initiation, promotion and progression in the multiple stages of carcinogenesis (30). For instance, berberine, an isoquinoline alkaloid, inhibits the metastatic potential of breast cancer cells via modulation of the Akt pathway (31). In this study, we examined the molecular mechanisms underlying the proapoptotic activities of 8-ADEQ in HL-60 human promyelocytic leukemia cells. From our study, 8-ADEQ potentially represents an apoptosis-inducing agent with applications in leukemia therapy.

\section{Materials and methods}

Chemical and reagents. 8-ADEQ (Fig. 1A) was prepared as previously described (22). RPMI-1640 medium, DMEM,
FBS, penicillin, and streptomycin were obtained from Life Technologies Inc. MTT, anti $\beta$-actin antibody, protein A, CCCP (carbonyl cyanide m-chlorophenylhydrazone), DAPI (4',6-diamidino-2-phenylindole), PMSF (phenylmethylsulfonyl fluoride), dithiothreitol, NAC ( $N$-acetylcysteine), BSO (buthionine sulfoximine), DCFH-DA (dichloro-dihydrofluorescein diacetate), acrylamide, bisacrylamide, sodium dodecyl sulfate, and all other chemicals were purchased from Sigma Chemical Co. and anti-caspase-8, -9, FADD antibodies were obtained from Pharmingen. Antibodies for caspase-3, -6 , PARP, Fas, FasL and the peroxidase conjugated secondary antibody were purchased from Santa Cruz Biotechnology, Inc. DiOC $_{6}$ (3,3'-dihexyloxacarbocyanine iodide) was perchased from Molecular Probes. Proteinase K, ribonuclease A, and TEMED were perchased from Bio-Rad Laboratories. Caspase inhibitors (Ac-DEVD-CHO, z-DEVD-fmk, z-IETD-fmk, z-LEHD-fmk, z-VAD-fmk) were purchased from Enzyme System Products, Inc. SiRNA and transfection reagents for FADD were purchased from Quiagen, Inc.

Cell culture. HL-60 human promyelocytic leukemia, U-937 human histocytic lymphoma, Jurkat human acute $\mathrm{T}$ cell leukemia, HeLa human negroid cervix epitheloid carcinoma, A172 human glioblastoma, A549 human lung adenocarcinoma cells were obtained from the Korean Cell Line Bank and cultured in RPMI-1640 or DMEM media supplemented with $10 \%$ heat-inactivated FBS, penicillin $(100 \mathrm{U} / \mathrm{ml})$, and streptomycin sulfate $(100 \mu \mathrm{g} / \mathrm{ml})$. Cells were maintained at $37^{\circ} \mathrm{C}$ in an atmosphere of $5 \% \mathrm{CO}_{2}$ in air.

MTT assay. The cells were seeded in each well containing $100 \mu \mathrm{l}$ of the medium supplemented with $10 \%$ FBS in a 96-well plate. After $24 \mathrm{~h}$, various concentrations of 8-ADEQ were added. After $48 \mathrm{~h}, 50 \mu \mathrm{l}$ of MTT $(5 \mathrm{mg} / \mathrm{ml}$ stock solution, in PBS) was added, and the plates were incubated for an additional $4 \mathrm{~h}$. After centrifugation, the medium was discarded and the formazan blue, which formed in the cells, was dissolved with $100 \mu \mathrm{l}$ DMSO. The optical density was measured at $540 \mathrm{~nm}$.

TUNEL assay. After treatment of cells with 8-ADEQ $(20 \mu \mathrm{M})$ for indicated times, cells were harvested and washed twice with ice-cold PBS. Then the cells were fixed and smeared with $4 \%$ paraformaldehyde on the slide glass. The fixed cells were incubated in permeabilization solution for 2 min on ice. TUNEL was performed using a kit (In situ Cell Death Detection kit) according to the standard protocol provided by the manufacturer. The 50- $\mu 1$ TUNEL reaction mixture was added on each sample, and the cells were incubated for $1 \mathrm{~h}$ at $37^{\circ} \mathrm{C}$ in a humidified atmosphere in the dark. After washed twice, the cells were incubated with converter-AP for additional $30 \mathrm{~min}$. Substrate solution was added, and the slides were incubated for $10 \mathrm{~min}$ at room temperature in the dark, followed by mounting coverslip and then examined under a light microscope.

DAPI assay. Cells were lysed in a solution containing $5 \mathrm{mM}$ Tris-HCl (pH 7.4), 1 mM EDTA, and 0.5\% (w/v) Triton X-100 for $20 \mathrm{~min}$ on ice. The lysate and supernatant after centrifugatation at 25,000 $\mathrm{g}$ for $20 \mathrm{~min}$ were sonicated for $10 \mathrm{sec}$, and 
A<smiles>CC(=O)Oc1ccc(/C=C/c2ncc3cccc(OC(C)=O)c3n2)cc1OC(C)=O</smiles>

B

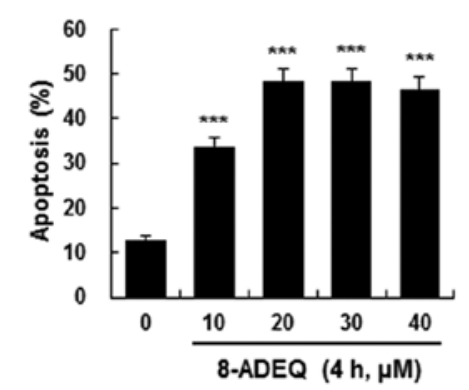

c

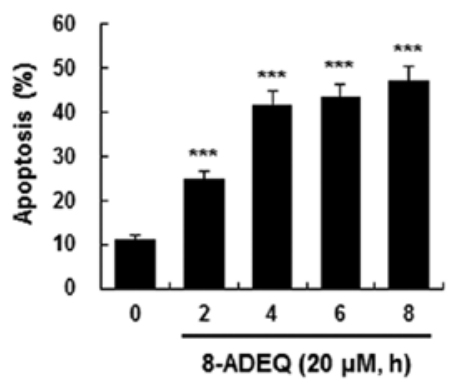

D

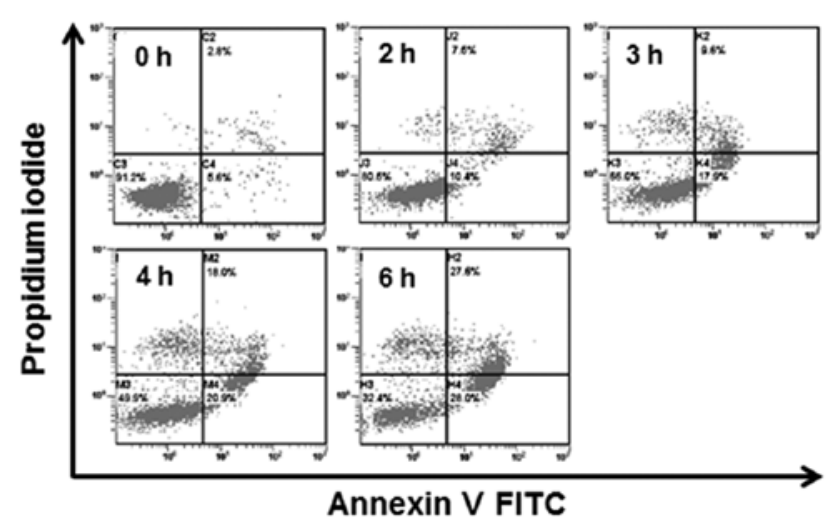

C

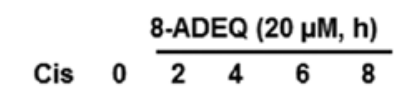
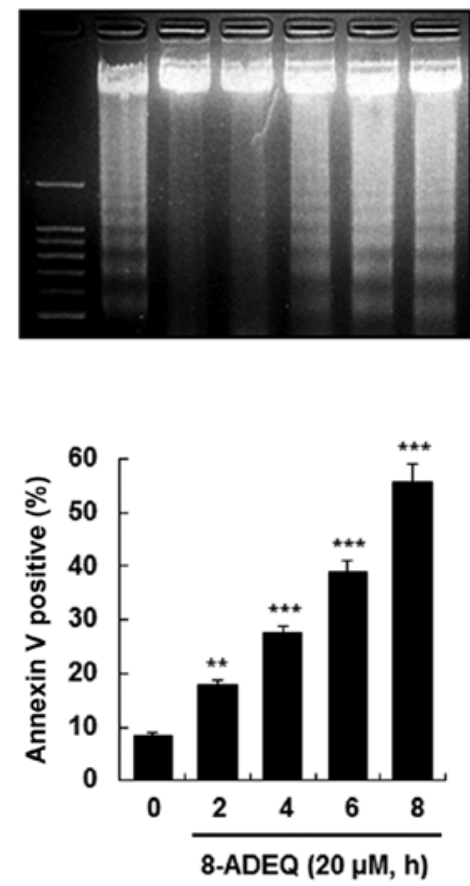

Figure 1. 8-ADEQ-induces apoptosis in HL-60 cells. (A) Chemical structure of 8-ADEQ. (B) HL-60 cells were treated with the indicated concentrations of 8-ADEQ and for the indicated times. The extent (\%) of DNA fragmentation was determined using DAPI as described in Materials and methods. (C) HL-60 cells were treated with $20 \mu \mathrm{M}$ 8-ADEQ for the indicated times, and DNA fragmentation was analyzed by $2 \%$ agarose gel electrophoresis. (D) HL-60 cells were treated with or without $20 \mu \mathrm{M}$ 8-ADEQ for the indicated times. Cells were co-stained with PI and FITC-conjugated Annexin V, and the translocation of PS was detected by flow cytometry after 8 -ADEQ treatment. Data presented are the means \pm SD of results from three independent experiments. ${ }^{* *} \mathrm{P}<0.01$ ${ }^{* * *} \mathrm{P}<0.001$ vs. control group.

the level of DNA in each fraction was measured by a fluorometric method using DAPI. The amount of the fragmented DNA was calculated as the ratio of the amount of DNA in the supernatant to that in the lysate.

DNA laddering. Cells under different treatments were collected, washed with ice-cold PBS twice and then lysed in $1 \mathrm{ml}$ of lysis buffer (50 mM Tris, $20 \mathrm{mM}$ EDTA, 0.1\% NP-40, pH 7.4) for $60 \mathrm{~min}$ at room temperature. The lysates were subsequently incubated with $5 \mu \mathrm{l}$ of RNase A $(1 \mathrm{mg} / \mathrm{ml})$ for $60 \mathrm{~min}$ at $37^{\circ} \mathrm{C}$. Proteinase K $(10 \mathrm{mg} / \mathrm{ml}, 10 \mu \mathrm{l})$ was then added to the lysates and incubated at $50^{\circ} \mathrm{C}$ overnight. DNA was extracted with an equal volume of phenol: chloroform: isoamyl alcohol (25:24:1). Purified DNA was resuspended in TE buffer $(10 \mathrm{mM}$ Tris, $1 \mathrm{mM}$ EDTA, $\mathrm{pH}$ 8.0). Electrophoresis was performed in a $2 \%(\mathrm{w} / \mathrm{v})$ agarose gel in $40 \mathrm{mM}$ Tris-acetate buffer (pH 7.4) at $50 \mathrm{~V}$ for $1 \mathrm{~h}$. The fragmented DNA was visualized by staining with ethidium bromide after electrophoresis (32).

Annexin V and PI double staining by flow cytometry. During apoptosis, exposure of phosphatidylserine on the exterior surface of the plasma membrane can be detected by the binding of fluorescenated Annexin V (Annexin V-FITC). This assay is combined with analysis of the exclusion of the plasma membrane integrity probe PI (33). For Annexin V and PI double staining, cells were suspended with $100 \mu \mathrm{l}$ of binding buffer (10 mM HEPES/NaOH, $140 \mathrm{mM} \mathrm{NaCl}, 2.5 \mathrm{mM} \mathrm{CaCl}_{2}$, pH 7.4) and stained with $5 \mu \mathrm{l}$ of FITC-conjugated Annexin V and $5 \mu 1$ of PI $(50 \mu \mathrm{g} / \mathrm{ml})$. The mixture was incubated for 15 min at room temperature in the dark and analyzed by the fluorescence-activated cell sorting (FACS) cater-plus flow cytometry (Becton-Dickinson Co., Heidelberg, Germany).

Luminescent caspase activity assay. The activity of caspases was measured using the specific substrates; caspase-3 (Ac-DEVD-pNA), caspase-8 substrate (Ac-IETD-pNA), and caspase-9 substrate (Ac-LEHD-pNA). The cells were incubated with caspase-8 inhibitor (z-IETD-fmk) or not, for $1 \mathrm{~h}$ at $37^{\circ} \mathrm{C}$, followed by the addition of 8-ADEQ $(20 \mu \mathrm{M})$. After $4 \mathrm{~h}$ of incubation in the absence of caspase- 8 inhibitor, cells were harvested, and then washed twice with cold PBS. The Caspase-Glo ${ }^{\circledR}$ 3/7, 8, 9 assay kits were used for detecting 
the specific caspase activities. Each Caspase-Glo reagent was prepared by adding the specific buffer to the specific luminogenic substrate and mixing. The equal volume of each Caspase-Glo reagent was added to the sample in the assay well. The luminescence of each sample was measured in a plate-reading luminometer.

Western blot analysis. Cells were harvested and washed twice with cold PBS. Cell pellets were then lysed in ice-cold cell extraction buffer (50 mM HEPES, pH 7.0, $250 \mathrm{mM} \mathrm{NaCl}$, $5 \mathrm{mM}$ EDTA, $0.1 \%$ NP-40, $0.1 \mathrm{mM}$ PMSF, $0.5 \mathrm{mM}$ dithiothreitol, $5 \mathrm{mM} \mathrm{NaF}, 0.5 \mathrm{mM}$ Na orthovanadate) containing $5 \mu \mathrm{g} / \mathrm{ml}$ each of leupeptin and aprotinin and incubated for $30 \mathrm{~min}$ at $4^{\circ} \mathrm{C}$. Cell debris was removed by microcentrifugation $(10,000 \mathrm{~g}, 5 \mathrm{~min})$, followed by quick freezing of the supernatants. Cellular proteins $(50 \mu \mathrm{g})$ were electroblotted onto nitrocellulose membrane following separation on a $10-15 \%$ SDS-polyacrylamide gel electrophoresis. The immunoblot was incubated for $1 \mathrm{~h}$ with blocking solution $(5 \%$ skim milk in TTBS), and then incubated for $4 \mathrm{~h}$ with a 1:1,000 dilution of primary antibody. Blots were washed three times with TTBS, and then incubated with a 1:1,000 dilution of horseradish peroxidase-conjugated secondary antibody for $1 \mathrm{~h}$ at room temperature, washed again three times with TTBS, and then developed by enhanced chemiluminescence.

Analysis of mitochondrial membrane potential (MMP, $\triangle \Psi m$ ). Changes in mitochondrial transmembrane potential were monitored by flow cytometric analysis. Cells were incubated with $50 \mathrm{nM} \mathrm{DiOC}_{6}$ for $30 \mathrm{~min}$, washed twice with PBS, and analyzed by flow cytometric analysis (Becton-Dickinson Co.) with excitation and emission settings of 484 and $500 \mathrm{~nm}$, respectively. To ensure that $\mathrm{DiOC}_{6}$ uptake was specific for $\Delta \Psi m$, we also treated cells with $100 \mu \mathrm{M} \mathrm{CCCP.} \mathrm{CCCP} \mathrm{was}$ used as a reference depolarizing agent of mitochondrial permeability transition.

Preparation of cytosolic proteins. Cells were collected by centrifugation at $200 \mathrm{~g}$ for $10 \mathrm{~min}$ at $4^{\circ} \mathrm{C}$. The cells were then washed twice with ice-cold PBS, and centrifuged at $200 \mathrm{~g}$ for $5 \mathrm{~min}$. The cell pellet obtained was then resuspended in ice-cold cell extraction buffer (20 mM HEPES-KOH, pH 7.5, $10 \mathrm{mM} \mathrm{KCl}, 1.5 \mathrm{mM} \mathrm{MgCl} 2,1 \mathrm{mM}$ EDTA, $1 \mathrm{mM}$ EGTA, $1 \mathrm{mM}$ dithiothreitol, $100 \mu \mathrm{M}$ PMSF, and protease inhibitor cocktail) for $30 \mathrm{~min}$ on ice. The cells were then homogenized with a glass dounce and a B-type pestle (80 strokes), homogenates were spun at $15,000 \mathrm{~g}$ for $15 \mathrm{~min}$ at $4^{\circ} \mathrm{C}$, and the supernatant (cytosolic fraction) was removed whilst taking care to avoid the pellet. The resulting supernatant was fractionated in SDS-polyacrylamide gels and transferred to nitrocellulose membranes fot immunoblot analysis using the indicated primary antibodies. Immunopositive bands were visualized by ECL kit (Amersham, Buckinghamshire, UK).

Immunoprecipitation. Cells treated with 8-ADEQ were harvested and washed twice with cold PBS. The cell pellets were resuspended and lysed in EBC buffer $(50 \mathrm{mM}$ Tris, $\mathrm{pH} 8.0,120 \mathrm{mM} \mathrm{NaCl}, 0.5 \% \mathrm{NP}-40,5 \mu \mathrm{g} / \mathrm{ml}$ leupeptin, $10 \mu \mathrm{g} / \mathrm{ml}$ aprotinin, $50 \mu \mathrm{g} / \mathrm{ml}$ PMSF, $0.2 \mathrm{mM}$ sodium orthovanadate, $100 \mathrm{mM} \mathrm{NaF}$ ) for $30 \mathrm{~min}$ at $4^{\circ} \mathrm{C}$. After centrifugation
$(10,000 \mathrm{~g}, 5 \mathrm{~min})$, protein concentrations were determined. Equal amount of protein $(100 \mu \mathrm{g})$ was incubated with anti-Fas and anti-FADD polyclonal antibodies for $12 \mathrm{~h}$ at $4^{\circ} \mathrm{C}$, followed by incubation with $20 \mu \mathrm{l}$ protein A-Sepharose beads for $4 \mathrm{~h}$. The protein complex was washed 4 times with EBC buffer and released from the beads by boiling in $6 \mathrm{X}$ sample buffer (350 mM Tris, pH 6.8, 10\% SDS, 30\% $\beta$-mercaptoethanol, $6 \%$ glycerol, $0.12 \%$ bromophenol blue) for $5 \mathrm{~min}$. The reaction mixture was then resolved by a 10-15\% SDS-PAGE gel, transferred to nitrocellulose membrane and probed with anticaspase-8, anti-Fas, anti-FasL monoclonal antibody. The blot was developed by enhanced chemiluminescence.

RNA interference. RNA interference of FADD was performed using a 21-base pair (bp) (including a 2-deoxynucleotide overhang) siRNA duplexes purchased from Qiagen. The sense strand nucleotide strand was UCACAGACUUUGGACAAAGdTdT. For transfection, siRNA duplexes $(200 \mathrm{nM})$ were introduced into the cells $\left(2 \times 10^{5}\right.$ cells $\left./ \mathrm{ml}\right)$ using RNAiFect transfection reagent (Qiagen) according to the manufacturer's instructions.

ROS detection (DCFH-DA assay). DCFH-DA was used to measure levels of ROS. The cells were harvested and suspended in media. DCFH-DA $(20 \mu \mathrm{M})$ was then added and incubated for $30 \mathrm{~min}$ at $37^{\circ} \mathrm{C}$. DCFH-DA was taken up by cells and, on deacetylation, formed a nonfluorescent DCFH. On oxidation, this became DCF. The fluorescent intensity was measured by flow cytometry. The histograms were analyzed by indicating the MFI.

Statistical analysis. Data presented are the means \pm SD of results from three independent experiments. Statistically significant values were compared using ANOVA and Dunnett's post hoc test, and P-values of $<0.05$ were considered statistically significant.

\section{Results}

8-ADEQ inhibits cell growth in various cancer cell lines. We first examined the cytotoxicity of 8-ADEQ using MTT assay in various cancer cell lines. 8-ADEQ showed different degrees of cytotoxicity on these cells as judged by $\mathrm{IC}_{50}$ and its value ranges from 7.59 to $143.88 \mu \mathrm{M}$ (Table I). Interestingly, 8-ADEQ was found to have significant cytotoxic effects on hematological cancer cell lines, such as HL-60, U937, and Jurkat. Since HL-60 cells were found to be the most sensitive to 8-ADEQ, further experiments were performed to evaluate the effects of 8-ADEQ on apoptosis and to identify the molecular mechanism involved in HL-60 cells.

8-ADEQ induces apoptosis in HL-60 cells. To determine whether the cytotoxic effect of 8-ADEQ is associated with the induction of apoptosis, HL-60 cells were treated with 8-ADEQ and the DNA fragmentation in the cells was evaluated. The DAPI assay revealed that 8-ADEQ induced DNA fragmentation in a dose- and time-dependent manner (Fig. 1B). To further characterize the end stage of apoptosis induced by 8-ADEQ, we examined whether 8-ADEQ induces a typical ladder pattern of internucleosomal DNA fragmentation, a hallmark of apoptosis. The laddering pattern of 
A

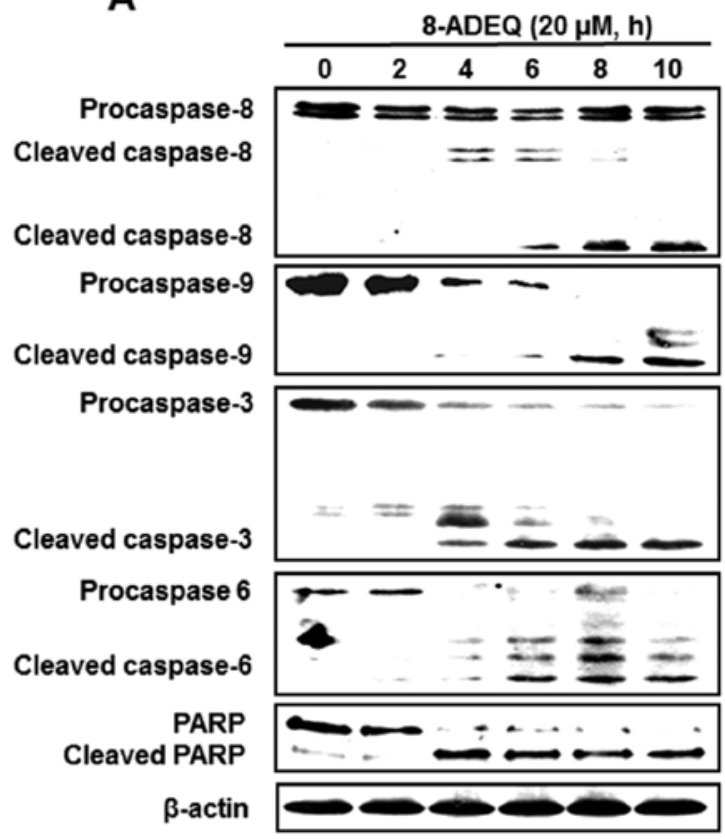

D

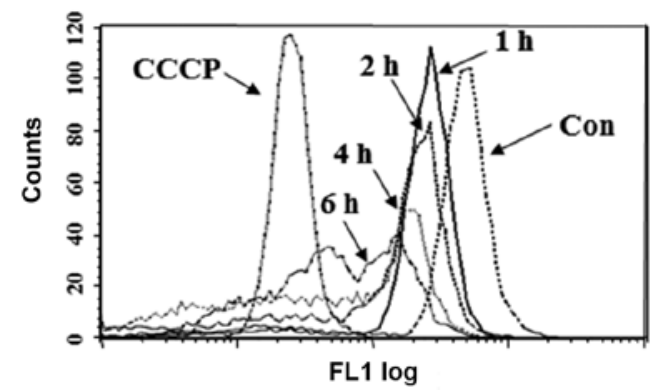

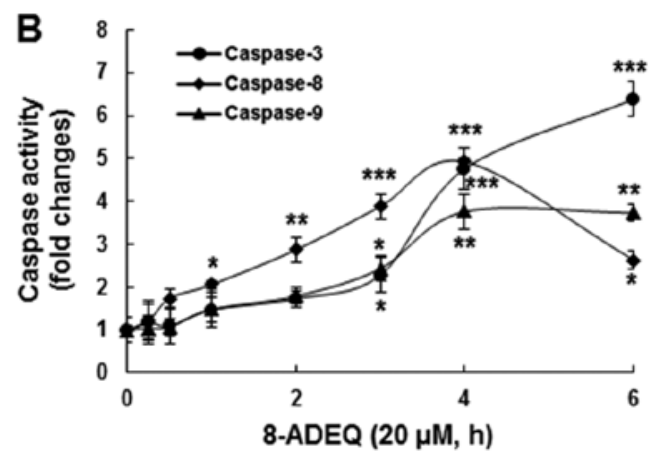

C

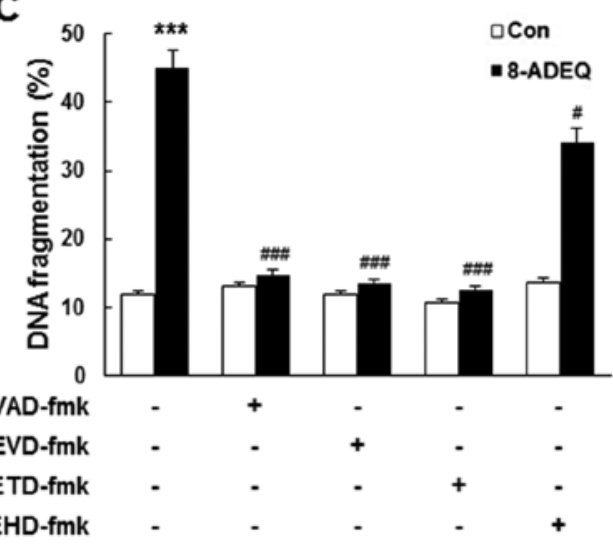

E

8-ADEQ $(20 \mu \mathrm{M}, \mathrm{h})$

Cytochrome $c$ (C)

a-tublin (C)

Figure 2. 8-ADEQ-treatment leads to caspase activation, loss of mitochondrial membrane potential, and cytosolic release of cytochrome $c$ in HL-60 cells. (A) HL-60 cells were treated with $20 \mu \mathrm{M}$ 8-ADEQ for the indicated times. Each protein fraction was detected by western blotting using specific antibodies. The amount of $\beta$-actin was used as an internal control. (B) 8-ADEQ induced caspase-3, -8, -9 activation as measured by a luminometric assay. HL-60 cells were treated with $20 \mu \mathrm{M} 8$-ADEQ for the indicated times. (C) HL-60 cells were pretreated with or without $50 \mu \mathrm{M} \mathrm{z-VAD-fmk,} \mathrm{z-DEVD-fmk,} \mathrm{z-IETD-fmk,}$ z-LEHD-fmk for $1 \mathrm{~h}$, and then treated with $20 \mu \mathrm{M}$ 8-ADEQ for $4 \mathrm{~h}$. The quantification of DNA fragmentation was with the DAPI assay. (D) Cells were treated with $20 \mu \mathrm{M}$ 8-ADEQ for the indicated times, stained with $\mathrm{DiOC}_{6}$, and analyzed by flow cytometry. CCCP $(100 \mu \mathrm{M})$ was used as a positive control. (E) HL-60 cells were treated with $20 \mu \mathrm{M}$ 8-ADEQ for the indicated times, and the cytosolic (C) fractions were prepared as described in Materials and methods. Cytochrome $c$ levels were analyzed by western blotting. $\alpha$-tubulin was used as the internal control. Data presented are the means \pm SD of results from three independent experiments. ${ }^{*} \mathrm{P}<0.05,{ }^{* *} \mathrm{P}<0.01,{ }^{* * *} \mathrm{P}<0.001$ vs. control group, ${ }^{\#} \mathrm{P}<0.05,{ }^{\# \#} \mathrm{P}<0.001$ vs. 8-ADEQ-treated group.

internucleosomal DNA fragmentation was found to occur in a time-dependent manner after treating HL-60 cells with 8-ADEQ (Fig. 1C). Furthermore, we assessed the translocation of phosphatidylserine (PS) using Annexin V and PI double staining. Treatment of HL-60 cells with 8-ADEQ resulted in a significant time-dependent enhancement in both the early and late stages of apoptosis (Fig. 1D).

8-ADEQ-induced apoptosis involves caspase, the loss of $\Delta \Psi_{m}$, and the release of cytochrome $c$. The caspase family of cysteine proteases plays a central role in apoptosis, a controlled demolition of the cellular architecture in response to diverse stimuli (34). To determine whether 8-ADEQinduced apoptosis is involved in the activation of the caspase cascade, HL-60 cells were treated with $20 \mu \mathrm{M}$ 8-ADEQ for various time-points, and activation of caspases was measured by western blotting. In consequence, time-dependent cleavage of procaspase-8, $-9,-3$ and -6 was observed by $20 \mu \mathrm{M}$ 8-ADEQ treatment. The activations of caspases were accompanied by the degradation of PARP, a target for caspase-3 during the apoptotic response (35). Cleavage of PARP was evident at 4 h post 8-ADEQ treatment and coincided with the appearance of activated caspase-3 (Fig. 2A). The increased enzymatic activity of caspase-3, $-8,-9$ was detected after the 8-ADEQ 
Table I. Cytotoxic activity of 8-ADEQ on various cancer cell lines.

\begin{tabular}{lcr}
\hline & Cell lines & $\mathrm{IC}_{50}(\mu \mathrm{M})$ \\
\hline HL-60 & Human promyelocytic leukemia & $7.59 \pm 1.54$ \\
U-937 & Human histocytic lymphoma & $9.43 \pm 2.85$ \\
Jurkat & Human acute T cell leukemia & $12.84 \pm 1.73$ \\
HeLa & Human cervical epitheloid carcinoma & $73.62 \pm 6.62$ \\
A172 & Human glioblastoma & $25.75 \pm 2.63$ \\
A549 & Human lung adenocarcinoma & $143.88 \pm 13.35$ \\
\hline
\end{tabular}

The values represent the means \pm SD of results from three independent experiments.

treatment, coincident with the observed cleaved forms of the caspases (Fig. 2B). The activation of caspase- 8 was detected earlier than that of the other monitored caspases.

To determine whether the activation of caspases was required for the induction of apoptosis by 8-ADEQ, we pretreated HL-60 cells with a number of caspase inhibitors. z-VAD-fmk (a broad caspase inhibitor), z-DEVD-fmk (a caspase-3 inhibitor), and z-IETD-fmk (a caspase-8 inhibitor), apparently inhibited 8-ADEQ-induced DNA fragmentation, whereas z-LEHD-fmk, an inhibitor of caspase-9 activity, had little effect on reducing DNA fragmentation compared to the other inhibitors (Fig. 2C). The results indicated that procaspase- 3 and procaspase- 8 were involved in the 8-ADEQinduced apoptosis in HL-60 cells. These observations indicated that the caspase cascade may be involved in 8-ADEQ-induced apoptosis. Thus caspase- 8 and -3 dependent pathways are the main stream in 8-ADEQ-induced apoptosis. Because 8-ADEQ also induced caspase- 9 cleavage, an initial caspase in the mitochondrial apoptotic pathway, we investigated whether 8-ADEQ was capable of inducing $\Delta \Psi m$ depolarization using $\mathrm{DiOC}_{6}$, a mitochondria-specific voltage-dependent dye. Treatment of cells with 8-ADEQ at $20 \mu \mathrm{M}$ caused the dissipation of $\Delta \Psi m$ in a time-dependent manner, as did CCCP, a positive control (Fig. 2D). Furthermore, the levels of cytosolic cytochrome $c$ were elevated by 8 -ADEQ in HL-60 cells, suggesting the involvement of the mitochondrial apoptotic pathway (Fig. 2E).

8-ADEQ induces apoptosis via the caspase-8-dependent pathway. Because 8-ADEQ induced caspase-8 activation at an early time-point, we further examined the mechanism of caspase-8 activation during 8-ADEQ-induced apoptosis using the caspase-8 inhibitor, z-IETD-fmk. Treatment with z-IETD-fmk completely inhibited 8-ADEQ-induced caspase-3, -8, and -9 activation using the caspase activity assay (Fig. 3A). In addition, 8-ADEQ-induced internucleosomal DNA fragmentation was significantly abolished in the presence of z-IETD-fmk (Fig. 3B and C). These results indicated that the procaspase- 8 activation is essential in the 8-ADEQ-induced apoptosis.

\section{8-ADEQ upregulates Fas and its ligand and increases the} formation of DISC. We demonstrated that procaspase- 8 was activated, and the activated caspase- 8 was required in the 8-ADEQ-induced apoptosis. Caspase- 8 acts as the initiator caspase in apoptosis that results from ligand-driven engagement of various death receptors such as TNFR1 and Fas (36), or from stimuli that include oxidative stress and DNA damage
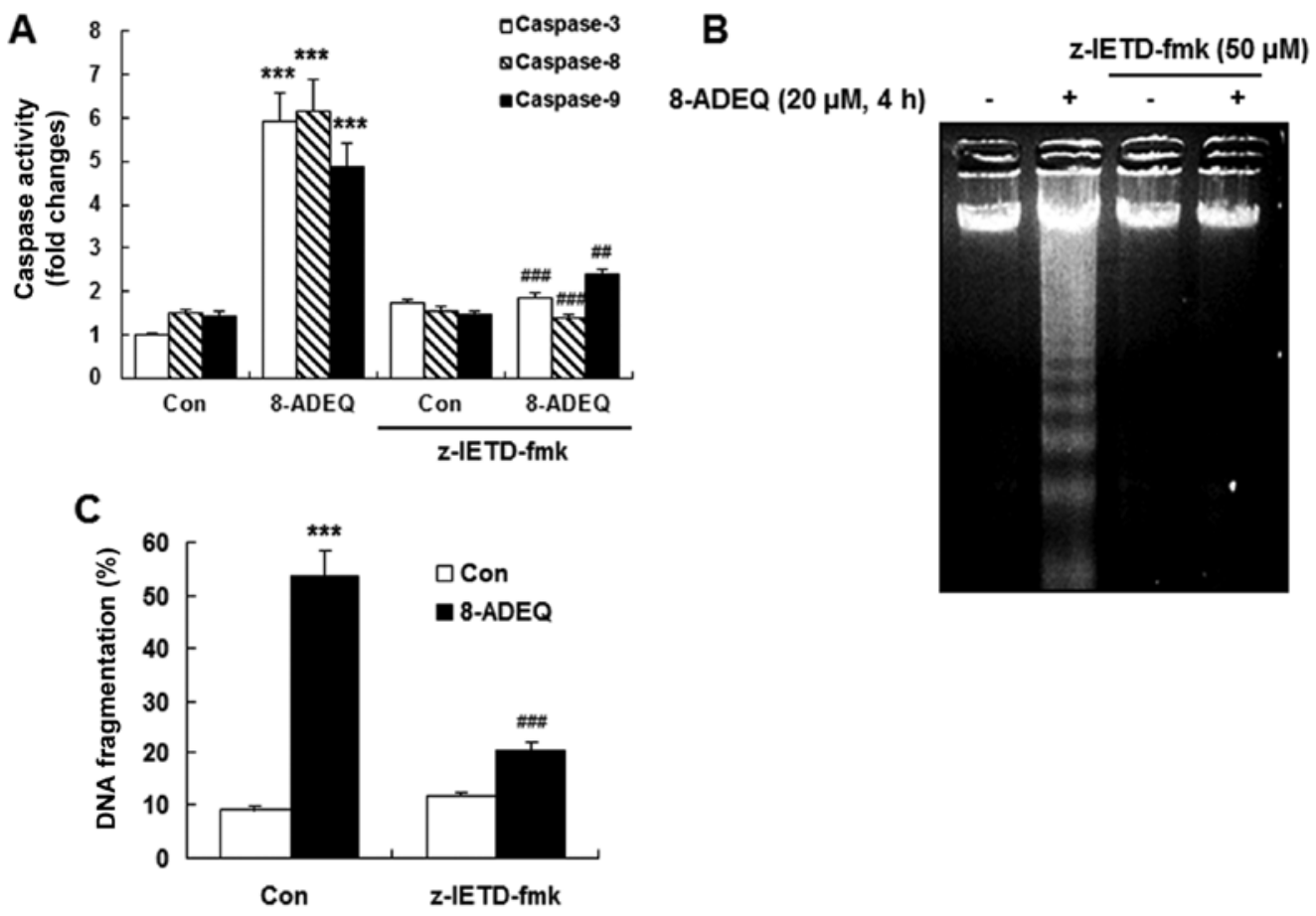

Figure 3. Requirement of caspase-8 for 8-ADEQ-induced apoptosis. (A) HL-60 cells were treated with $20 \mu \mathrm{M} 8$-ADEQ for $4 \mathrm{~h}$ in the presence and absence of caspase- 8 inhibitor (z-IETD-fmk). Caspase activity was measured by using Caspase-Glo assay. (B) DNA ladders were detected by $2 \%$ agarose gel electrophoresis. (C) The apoptotic cell percentage for DNA fragmentation was measured by the DAPI assay. Data presented are the means \pm SD of results from three independent experiments. ${ }^{* * *} \mathrm{P}<0.001$ vs. control group, ${ }^{\# \#} \mathrm{P}<0.01,{ }^{\# \#} \mathrm{P}<0.001$ vs. 8-ADEQ-treated group. 
A

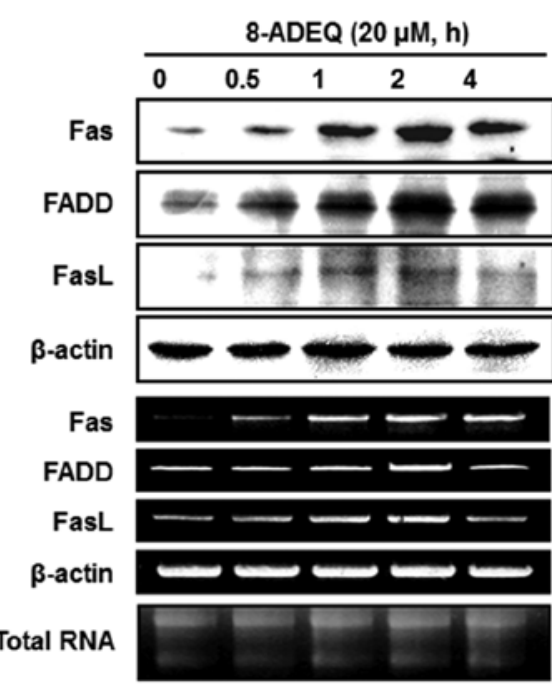

C

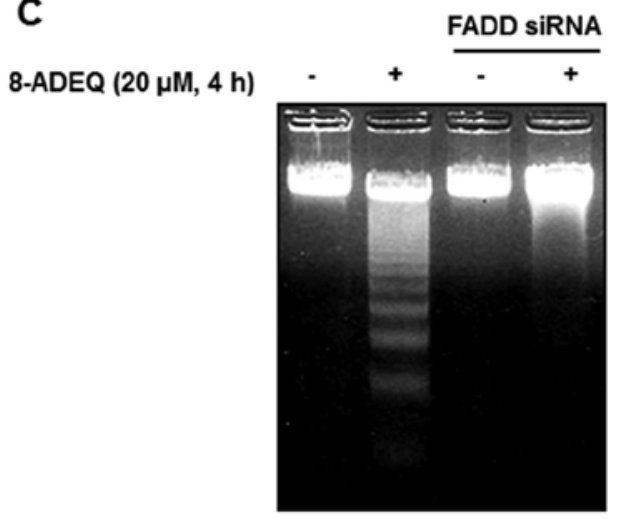

E

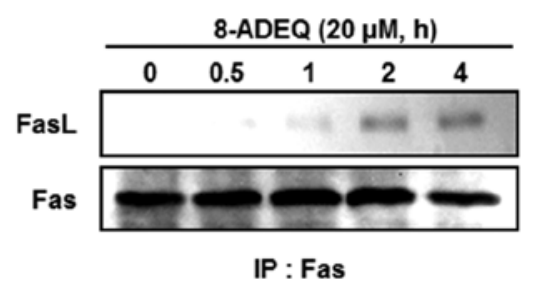

B

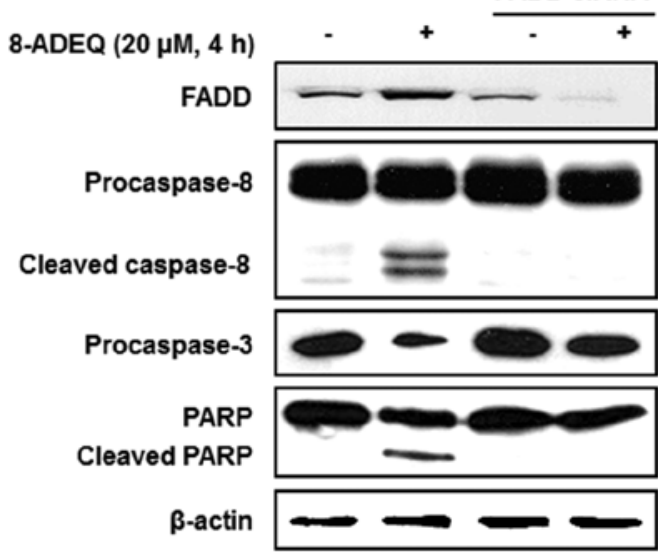

D

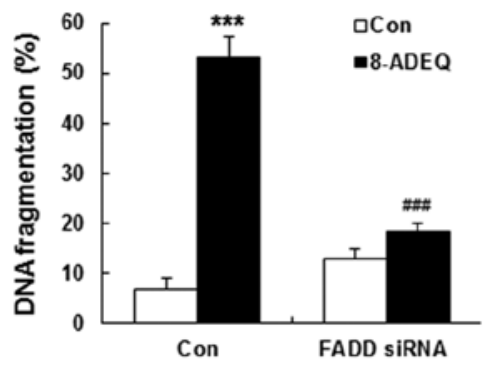

F

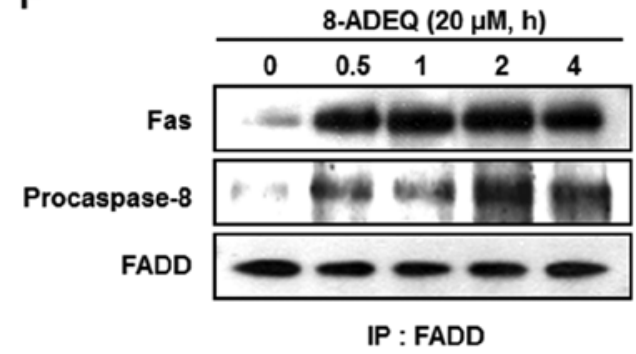

Figure 4. 8-ADEQ induces Fas-mediated apoptosis. (A) HL-60 cells were treated with $20 \mu \mathrm{M}$ 8-ADEQ for the indicated times. Each protein fraction was detected by western blotting using anti-Fas, FADD, and FasL antibodies. $\beta$-actin levels were used as internal control. (B) HL-60 cells were transfected with Fas siRNA and were treated with $20 \mu \mathrm{M} 8$-ADEQ for an additional $4 \mathrm{~h}$. Cleavage of procaspase-8, procaspase-3, and PARP in the FADD siRNA transfected cells were analyzed by western blotting. $\beta$-actin levels were used as internal control. (C) Fragmented DNA laddering was analyzed by $2 \%$ agarose gel electrophoresis. (D) The apoptotic cell percentages for DNA fragmentation were measured by the DAPI assay. (E and F) In response to the 8-ADEQ-treated HL-60 cells for the indicated time-points, Fas-related proteins associated with each other. Cell lysates were immunoprecipitated with anti-Fas antibody or anti-FADD antibody, followed by immunoblotting with anti-FasL, anti-Fas, and anti-procaspase-8 antibodies. Data presented are the means \pm SD of results from three independent experiments. ${ }^{* * *} \mathrm{P}<0.001$ vs. control group, ${ }^{\# \# \#} \mathrm{P}<0.001$ vs. 8 -ADEQ-treated group.

(12). To enhance the caspase- 8 initiation, an adaptor protein, FADD is also required to be recruited to the receptor called DISC (37). To determine whether 8-ADEQ-induced caspase-8 activation involves the death receptor pathway, HL-60 cells were treated with $20 \mu \mathrm{M}$ 8-ADEQ for various time-points, and the Fas, FasL and FADD protein and mRNA level changes were monitored by western blotting and RT-PCR, respectively. The expression levels of the death receptor related proteins and their mRNA (Fas, FADD and FasL) were apparently increased by 8 -ADEQ in a time-dependent manner (Fig. 4A).
It has been known that FADD plays an important role to induce an apoptosis signal (37). To further confirm the requirement of FADD in 8-ADEQ-induced apoptosis, we transiently transfected HL-60 cells with FADD siRNA, leading to a complete reduction of the protein levels of FADD in the cells (Fig. 4B). The FADD siRNA-transfected cells were then treated with 8-ADEQ $(20 \mu \mathrm{M})$ for $4 \mathrm{~h}$. The knockdown of FADD significantly prevented the 8-ADEQ-induced cleavage of procaspase-8, procaspase-3, and PARP (Fig. 4B). We also observed that 8-ADEQ-induced DNA fragmentation 
A
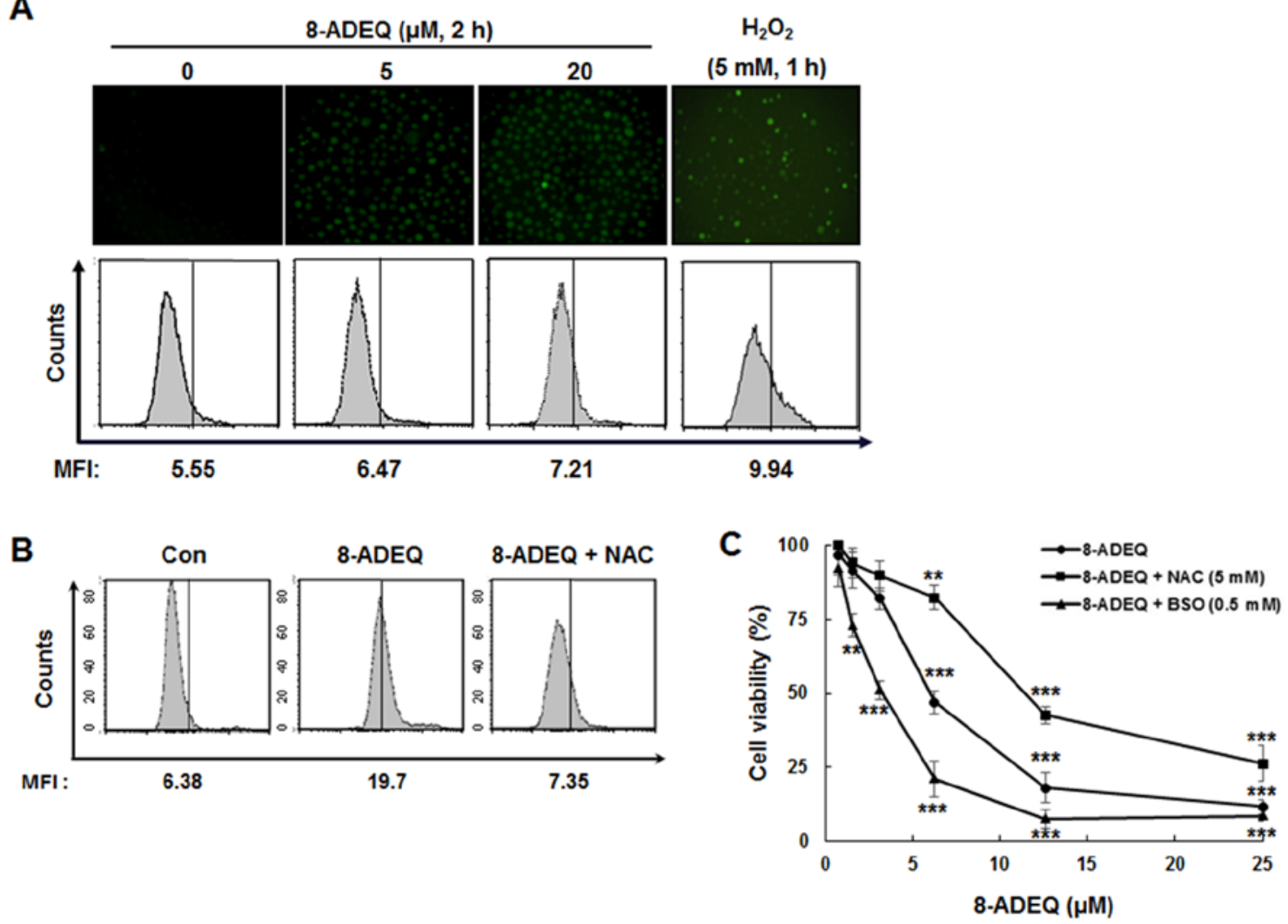

D

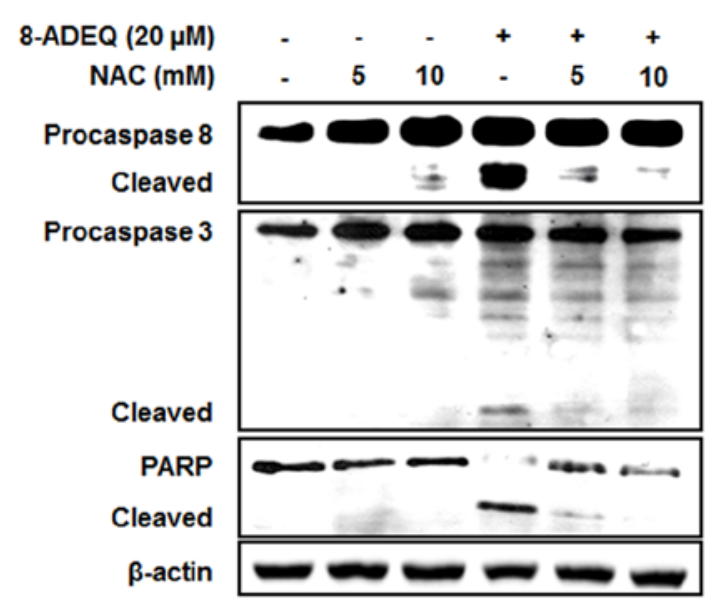

E

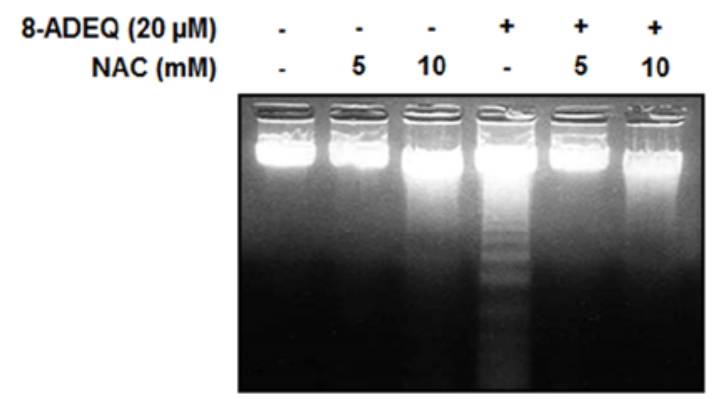

Figure 5. 8-ADEQ treatment of HL-60 cells leads to ROS generation and ROS-mediated apoptosis. (A) HL-60 cells were stimulated with 8-ADEQ, and then treated with DCFH-DA. Representative images were taken with a light microscope and the histograms indicative of DCF fluorescence were obtained with a flow cytometer. The histograms are expressed as indicating the MFI (mean fluorescence intensity). $\mathrm{H}_{2} \mathrm{O}_{2}$-treated group was used as a positive control. (B) To inhibit the ROS production, cells were pretreated with NAC $(5 \mathrm{mM})$ for $1 \mathrm{~h}$. (C) The cell viability of 8-ADEQ-treated cell was measured in presence of NAC $(5 \mathrm{mM})$ or BSO $(0.5 \mathrm{mM})$. (D) The cleavage in caspases and PARP in 8-ADEQ-treated HL-60 cells in the presence or absence of NAC $(5$ and $10 \mathrm{mM})$ was detected by western blotting. $\beta$-actin levels served as an internal control. (E) The blockage of fragmented DNA laddering in 8-ADEQ-treated HL-60 cells in the presence or absence of NAC was determined by $2 \%$ agarose gel electrophoresis. Data presented are the means \pm SD of results from three independent experiments. ${ }^{* *} \mathrm{P}<0.01,{ }^{* * *} \mathrm{P}<0.001$ vs. control group.

was completely prevented in the FADD siRNA-transfected cells, as seen by either the $2 \%$ agarose gel electrophoresis or DAPI staining (Fig. 4C and D). Therefore, FADD-caspase8-mediated apoptosis plays a pivotal role in the observed apoptotic induction by 8-ADEQ in HL-60 cells.

Fas and FasL are cell surface membrane proteins that belong to the TNF- $\alpha$ superfamily proteins and FasL trimer binds three Fas molecules (36). Because the death domains present in each receptor chain have a propensity to associate with one another, Fas ligation leads to clustering of the death domains. Then, an adaptor protein, FADD also binds its own death domain to the clustered receptor death domains. FADD also contains a death effector domain that binds to an analogous domain repeated in procaspase-8, as part of forming the DISC. Upon recruitment by FADD, procaspase- 8 oligomerization drives its activation through self-cleavage (38). To identify whether the DISC formation results in activation of procaspase-8 in 8-ADEQ-induced apoptosis, we immunoprecipitated 
Fas and detected bound FasL; FADD and detected bound Fas and procaspase- 8 by western blotting. We observed that Fas is associated with FADD, FasL, and procaspase- 8 and all these proteins were detected in the Fas immunoprecipitations and at a time-point earlier than that required for first detection of typical apoptotic features (Fig. 4E and F). These data suggested that 8-ADEQ treatment leads to formation of DISC and that it precedes the activation of procaspase- 8 .

8-ADEQ induces ROS-mediated apoptosis. It is known that formation of ROS is an early signal that mediates apoptosis (39), and a recent study indicated that activation of Fas was linked to generation of ROS in some cell lines (40). To test the possibility that ROS are required for 8-ADEQ-induced apoptosis, we first measured the levels of ROS using a flow cytometric assay. After treatment with 8-ADEQ for $2 \mathrm{~h}$, generation of ROS appeared in a concentration-dependent manner (Fig. 5A) and this ROS generation was blocked by pretreatment of NAC, antioxidant (Fig. 5B). To determinate whether the generation of ROS is a crucial step in 8-ADEQ-induced cell death, we examined the cell viability of 8-ADEQ-treated HL-60 cells in the presence of NAC, or BSO, an inhibitor of GSH synthesis. Pretreatment of cells with NAC completely inhibited the 8-ADEQ-induced cell death, whereas BSO pretreatment, resulting in GSH depletion, and enhanced cell death by 8-ADEQ (Fig. 5C). Furthermore, NAC potently inhibited the 8-ADEQ-induced activation of caspase-8, and -3 and DNA fragmentation (Fig. 5D and E), and this indicated that ROS was required for 8-ADEQ-induced apoptosis.

\section{Discussion}

As resveratrol has been found to have a variety of desirable effects with respect to various cell types (41), a number of resveratrol analogues were also evaluated for their biological activities $(21,26,27)$. With respect to various lead compounds, a series of styrylquinazoline derivatives were synthesized with the variation of the benzene ring to a quinazoline ring. There are reported pharmacological activities of these styrylquinazoline derivatives; these include HIV integrase inhibitors and $\mathrm{PGE}_{2}$ production inhibitors $(22,42)$. (E)-8-acetoxy-2-[2(3,4-diacetoxyphenyl)ethenyl]-quinazoline (8-ADEQ) was also found to have anti-proliferative effects on human cervical cancer HeLa cells by DNA damage-mediated $\mathrm{G}_{2} / \mathrm{M}$ cell cycle arrest via activation of both Chk1/2-Cdc25 and p53-p21 ${ }^{\mathrm{CIP} 1 /}$ WAF1 through the ATM/ATR pathways (23). However, the cytotoxic and apoptosis-inducing activities of 8-ADEQ on leukemia had not been studied in detail. In this study, we first determined that 8-ADEQ-treated HL-60 cells went into apoptotic cell death, characterized by several morphological changes, membrane blebbing, chromatin condensation, DNA cleavages, and PS exposure.

Apoptosis is a fundamental cellular activity and provides protection against cancer development by eliminating genetically altered cells and hyper-proliferative cells. It has been demonstrated that defects in apoptosis signaling pathways contribute to carcinogenesis and chemoresistance (43). As mentioned above, there are two major apoptotic pathways: the extrinsic death receptor-mediated pathway and the intrinsic mitochondria-mediated pathway. Both of these pathways are regulated by caspases, which are responsible, either directly or indirectly, for cleavage of cellular proteins, a characteristic of apoptosis (34). In this study, 8-ADEQ increased the levels of caspase-8, $-9,-3$, and -6 and cleaved PARP in a time-dependent manner. By monitoring the kinetic activities of caspase- $8,-3$ and -9 by using luminometric assay with specific substrates, caspase- 8 was initially activated, followed by the other caspases including caspase-3 and -9. Pretreatment with various caspase inhibitors markedly prevented 8-ADEQ-induced DNA fragmentation (Fig. 2). These findings indicated that caspase-3 and -8 play fundamental roles in 8-ADEQ-induced apoptosis in HL-60 cells. It is noteworthy that specific inhibition of caspase-9 by z-LEHD-fmk had only partial inhibitory effect on 8-ADEQ-stimulated apoptosis. In this regard, it appears that activation of the intrinsic mitochondria-mediated pathway alone is not sufficient to explain the apoptotic effects of 8-ADEQ in HL-60 leukemia cells. The next interesting result emerged after the use of a specific caspase- 8 inhibitor. In general, the activation of procaspase- 8 precedes those of procaspase- 3 , and caspase- 3 is activated prior to caspase- 6 , and may be responsible for activation of caspase- 6 (34). Our data clearly showed that the inhibition of caspase- 8 activity blocked the 8-ADEQ-induced activation of caspase-8, -3 and -9, as seen by using luminogenic substrates. In addition, it was found that a caspase-8 inhibitor significantly inhibited 8-ADEQ-induced apoptosis as determined by DNA fragmentation. Therefore, we suggest that apoptosis induced by 8 -ADEQ was mediated via a caspase-8-dependent mechanism.

Caspase- 8 acts as the initiator caspase in apoptosis resulting from ligand-driven engagement of death receptors such as FasL, TRAIL, and TNFR1 (36), or from the stimuli, including oxidative stress and DNA damage (12). In this study, Fas expression was markedly increased in HL-60 cells treated with 8-ADEQ, while that for FasL was only mildly increased. We also showed that 8-ADEQ changed not only the expression of Fas-mediated proteins but also their recruitment to Fas. 8-ADEQ resulted in oligomerization of receptors at the cell membrane and formation of DISC that included the adapter protein FADD. This led to activation of caspase-8, and is consistent with the notion presented by many reports $(37,44)$. Our results conclusively suggest that activation of caspase- 8 is the initial step in 8-ADEQ-induced apoptosis through DISC formation with FasL, Fas, FADD, and procaspase-8. In support of this, cells transfected with FADD siRNA showed a clear diminution of 8-ADEQ-induced cleavage of caspase-8, caspase-3 and PARP and DNA fragmentation. Therefore, 8-ADEQ-induced caspase-8 activation is probably due to the stimulation of the death receptors.

Many apoptosis-inducing agents are accompanied by loss of MMP, representing a decisive point of irreversible process in the induction of apoptosis (45). From loss of MMP, cytochrome $c$ and other pro-apoptotic proteins are released from the mitochondrial intermembrane space into the cytosol where a caspase cascade is initiated (46). Cytochrome $c$ release into cytosol by 8 -ADEQ indicated that MMP was reduced during 8-ADEQ-induced apoptosis. Bid, a $\mathrm{BH} 3$-only proapoptotic member of the Bcl-2 family, undergoes proteolysis by caspase-8, previously activated by cell surface death receptors such as Fas and TNF. Truncated Bid (tBid) translocates to mitochondria and binds to anti-apoptotic proteins such as 
Bcl-2 and Bcl-xL, and that leads to a conformational change in Bax, mitochondrial depolarization, and cytochrome $c$ release from mitochondria (47). Conformationally altered Bax also stimulates the cytochrome $c$-releasing activity of Bid by cell surface death receptors such as Fas and TNF and is antagonized by Bcl-2 (45). It is not known whether apoptosisinducing effects of 8-ADEQ through MMP depolarization and cytosolic cytochrome $c$ release are caused by a death receptor-caspase-8-dependent pathway or are a direct effect on mitochondria, and this remains to be determined.

Several reports have suggested that oxidative stress is a common mediator of several systems of apoptosis (40), although the role of ROS in apoptosis induction remains controversial. It has been reported that ROS act in the oxidation of the mitochondrial pores, leading to the release of cytochrome $c$ from the intracellular membrane (10). On the other hand, it is shown that ROS promote the upstream elements of Fas-mediated signaling, as the cell death induced by Fas receptor has been suggested to be redox-regulated, or dependent on ROS (40). The mechanism by which 8-ADEQ promotes DISC formation appears to be dependent on ROS generation since the 8-ADEQ-induced ROS generation and activation of caspase- 8 and caspase- 3 and DNA fragmentation were prevented by antioxidant, NAC, treatment. Therefore, the effects of ROS may be on caspase- 8 or other initiator death receptors. It is not yet known whether 8-ADEQ directly generates ROS, which then affects Fas expression and the association of Fas-related protein, or 8-ADEQ-induced Fas receptor activation induces ROS and then alters the redox status. Here we showed that 8-ADEQ induced oxidative stress, and induced DISC assembly, followed by caspase- 8 activation and apoptosis. These data support other reports on modifying cellular oxidative status or levels of antioxidant defenses can alter the sensitivity to Fas-induced apoptosis (48).

In conclusion, our results demonstrated that 8-ADEQ inhibited the viability of HL-60 cells and these effects were mediated through induction of apoptosis. 8-ADEQ induced the activation of caspase- $3,-6,-8$, and -9 , and accumulation of ROS. In addition, a caspase- 8 inhibitor completely abolished caspase-3 and caspase-9 activation, and subsequent DNA fragmentation by 8 -ADEQ. Therefore, caspase- 8 plays a key role in 8-ADEQ-stimulated apoptosis through a potent induction of Fas-mediated signaling. Moreover, the antioxidant NAC significantly attenuated the 8-ADEQ effects on caspase-8, and caspase- 3 activities and DNA fragmentation. Based on these findings, we suggest that 8-ADEQ, via its potent apoptotic activity, has the potential as a therapeutic and chemopreventive agent for leukemia.

\section{Acknowledgements}

This study was supported by the research grant from the Korea Food Research Institute (E0145202).

\section{References}

1. Debatin KM: Apoptosis pathways in cancer and cancer therapy. Cancer Immunol Immunother 53: 153-159, 2004.

2. Previati M, Lanzoni I, Corbacella E, Magosso S, Guaran V, Martini A and Capitani S: Cisplatin-induced apoptosis in human promyelocytic leukemia cells. Int J Mol Med 18: 511-516, 2006.
3. Fulda S, Strauss G, Meyer E and Debatin KM: Functional CD95 ligand and CD95 death-inducing signaling complex in activation-induced cell death and doxorubicin-induced apoptosis in leukemic T cells. Blood 95: 301-308, 2000

4. Odoux C and Albers A: Additive effects of TRAIL and paclitaxel on cancer cells: Implications for advances in cancer therapy. Vitam Horm 67: 385-407, 2004.

5. Karpinich NO, Tafani M, Rothman RJ, Russo MA and Farber JL: The course of etoposide-induced apoptosis from damage to DNA and $\mathrm{p} 53$ activation to mitochondrial release of cytochrome $c$. J Biol Chem 277: 16547-16552, 2002.

6. Clarke PG: Apoptosis: From morphological types of cell death to interacting pathways. Trends Pharmacol Sci 23: 308-309, author reply 310, 2002.

7. Wajant H: The Fas signaling pathway: More than a paradigm. Science 296: 1635-1636, 2002.

8. Debatin KM and Krammer PH: Death receptors in chemotherapy and cancer. Oncogene 23: 2950-2966, 2004.

9. Kaufmann SH and Earnshaw WC: Induction of apoptosis by cancer chemotherapy. Exp Cell Res 256: 42-49, 2000.

10. Giles GI: The redox regulation of thiol dependent signaling pathways in cancer. Curr Pharm Des 12: 4427-4443, 2006.

11. Roos WP and Kaina B: DNA damage-induced cell death by apoptosis. Trends Mol Med 12: 440-450, 2006.

12. Devadas S, Hinshaw JA, Zaritskaya L and Williams MS: Fas-stimulated generation of reactive oxygen species or exogenous oxidative stress sensitize cells to Fas-mediated apoptosis. Free Radic Biol Med 35: 648-661, 2003.

13. Micheau O, Solary E, Hammann A and Dimanche-Boitrel MT: Fas ligand-independent, FADD-mediated activation of the Fas death pathway by anticancer drugs. J Biol Chem 274: 7987-7992, 1999.

14. Santiago B, Galindo M, Palao G and Pablos JL: Intracellular regulation of Fas-induced apoptosis in human fibroblasts by extracellular factors and cycloheximide. J Immunol 172: 560-566, 2004.

15. Shen HM and Pervaiz S: TNF receptor superfamily-induced cell death: Redox-dependent execution. FASEB J 20: 1589-1598, 2006.

16. Reinehr R, Becker S, Eberle A, Grether-Beck S and Häussinger D: Involvement of NADPH oxidase isoforms and Src family kinases in CD95-dependent hepatocyte apoptosis. J Biol Chem 280: 27179-27194, 2005.

17. Bishayee K, Mondal J, Sikdar S and Khuda-Bukhsh AR: Condurango (Gonolobus condurango) extract activates fas receptor and depolarizes mitochondrial membrane potential to induce ROS-dependent apoptosis in cancer cells in vitro: CE-treatment on HeLa: a ROS-dependent mechanism. J Pharmacopuncture 18: 32-41, 2015.

18. Frémont L: Biological effects of resveratrol. Life Sci 66: 663-673, 2000.

19. Bhat KP and Pezzuto JM: Cancer chemopreventive activity of resveratrol. Ann NY Acad Sci 957: 210-229, 2002.

20. Savouret JF and Quesne M: Resveratrol and cancer: A review. Biomed Pharmacother 56: 84-87, 2002.

21. Bavaresco L, Fregoni C, Cantù E and Trevisan M: Stilbene compounds: From the grapevine to wine. Drugs Exp Clin Res 25: 57-63, 1999.

22. Park JH, Min HY, Kim SS, Lee JY, Lee SK and Lee YS: Styrylquinazolines: A new class of inhibitors on prostaglandin E2 production in lipopolysaccharide-activated macrophage cells. Arch Pharm (Weinheim) 337: 20-24, 2004.

23. Kim JY, Choi HE, Lee HH, Shin JS, Shin DH, Choi JH, Lee YS and Lee KT: Resveratrol analogue (E)-8-acetoxy-2-[2-(3,4diacetoxyphenyl)ethenyl]-quinazoline induces $\mathrm{G}_{2} / \mathbf{M}$ cell cycle arrest through the activation of ATM/ATR in human cervical carcinoma HeLa cells. Oncol Rep 33: 2639-2647, 2015.

24. Hung LM, Chen JK, Lee RS, Liang HC and Su MJ: Beneficial effects of astringinin, a resveratrol analogue, on the ischemia and reperfusion damage in rat heart. Free Radic Biol Med 30: 877-883, 2001.

25. Aldawsari FS, Aguiar RP, Wiirzler LA, Aguayo-Ortiz R, Aljuhani N, Cuman RK, Medina-Franco JL, Siraki AG and Velázquez-Martínez CA: Anti-inflammatory and antioxidant properties of a novel resveratrol-salicylate hybrid analog. Bioorg Med Chem Lett 26: 1411-1415, 2016.

26. Larrosa M, Tomás-Barberán FA and Espín JC: The grape and wine polyphenol piceatannol is a potent inducer of apoptosis in human SK-Mel-28 melanoma cells. Eur J Nutr 43: 275-284, 2004. 
27. Wang $Y$, Wang B, Cheng J, Yang L, Liu ZL, Balan K, Pantazis $\mathrm{P}$, Wyche JH and Han Z: FADD-dependent apoptosis induction in Jurkat leukemia T-cells by the resveratrol analogue, 3,4,5-trihydroxy-trans-stilbene. Biochem Pharmacol 69: 249-254, 2005.

28. Richard N, Porath D, Radspieler A and Schwager J: Effects of resveratrol, piceatannol, tri-acetoxystilbene, and genistein on the inflammatory response of human peripheral blood leukocytes. Mol Nutr Food Res 49: 431-442, 2005.

29. Choi YJ, Yang KM, Kim SD, Yoo YH, Lee SW, Seo SY, Suh H, Yee ST, Jeong MH and Jo WS: Resveratrol analogue HS-1793 induces the modulation of tumor-derived T cells. Exp Ther Med 3: 592-598, 2012

30. Ortín I, González JF, Cuesta EL, Manguan-García C, Perona R and Avendaño C: Cytotoxicity mechanisms of pyrazino[1,2-b] isoquinoline-4-ones and SAR studies. Bioorg Med Chem 17: 8040-8047, 2009.

31. Kuo HP, Chuang TC, Tsai SC, Tseng HH, Hsu SC, Chen YC, Kuo CL, Kuo YH, Liu JY and Kao MC: Berberine, an isoquinoline alkaloid, inhibits the metastatic potential of breast cancer cells via Akt pathway modulation. J Agric Food Chem 60: 9649-9658, 2012.

32. Khodarev NN, Sokolova IA and Vaughan AT: Mechanisms of induction of apoptotic DNA fragmentation. Int J Radiat Biol 73: 455-467, 1998

33 Pozarowski P, Grabarek J and Darzynkiewicz Z: Flow cytometry of apoptosis. Curr Protoc Cell Biol: Chapter 18: Unit 18.8, 2004.

34. Fan TJ, Han LH, Cong RS and Liang J: Caspase family proteases and apoptosis. Acta Biochim Biophys Sin (Shanghai) 37: 719-727, 2005.

35. Kaufmann SH, Desnoyers S, Ottaviano Y, Davidson NE and Poirier GG: Specific proteolytic cleavage of poly(ADP-ribose) polymerase: An early marker of chemotherapy-induced apoptosis. Cancer Res 53: 3976-3985, 1993.

36. Ouyang L, Shi Z, Zhao S, Wang FT, Zhou TT, Liu B and Bao JK: Programmed cell death pathways in cancer: A review of apoptosis, autophagy and programmed necrosis. Cell Prolif 45: 487-498, 2012.
37. Imtiyaz HZ, Rosenberg S, Zhang Y, Rahman ZS, Hou YJ, Manser T and Zhang J: The Fas-associated death domain protein is required in apoptosis and TLR-induced proliferative responses in B cells. J Immunol 176: 6852-6861, 2006.

38. Muzio M: Signalling by proteolysis: Death receptors induce apoptosis. Int J Clin Lab Res 28: 141-147, 1998.

39. Nordberg J and Arnér ES: Reactive oxygen species, antioxidants, and the mammalian thioredoxin system. Free Radic Biol Med 31: 1287-1312, 2001

40. Circu ML and Aw TY: Reactive oxygen species, cellular redox systems, and apoptosis. Free Radic Biol Med 48: 749-762, 2010.

41. Bhat KPL, Kosmeder JW II and Pezzuto JM: Biological effects of resveratrol. Antioxid Redox Signal 3: 1041-1064, 2001.

42. Lee JY, Park JH, Lee SJ, Park H and Lee YS: Styrylquinazoline derivatives as HIV-1 integrase inhibitors. Arch Pharm (Weinheim) 335: 277-282, 2002.

43. Hickman JA: Apoptosis induced by anticancer drugs. Cancer Metastasis Rev 11: 121-139, 1992.

44. Jin Z and El-Deiry WS: Distinct sgnaling pathways in TRAILversus tumor necrosis factor-induced apoptosis. Mol Cell Biol 26: 8136-8148, 2006

45. Tait SW and Green DR: Mitochondria and cell death: Outer membrane permeabilization and beyond. Nat Rev Mol Cell Biol 11: 621-632, 2010.

46. Zhang X, Zhang S, Zhu S, Chen S, Han J, Gao K, Zeng JZ and Yan X: Identification of mitochondria-targeting anticancer compounds by an in vitro strategy. Anal Chem 86: 5232-5237, 2014.

47. Desagher S, Osen-Sand A, Nichols A, Eskes R, Montessuit S, Lauper S, Maundrell K, Antonsson B and Martinou JC: Bid-induced conformational change of $\mathrm{Bax}$ is responsible for mitochondrial cytochrome $c$ release during apoptosis. J Cell Biol 144: 891-901, 1999.

48. Trachootham D, Lu W, Ogasawara MA, Nilsa RD and Huang P: Redox regulation of cell survival. Antioxid Redox Signal 10: 1343-1374, 2008. 